Three resurrected species of the genus Bulbothrix Hale (Parmeliaceae, Lichenized Fungi)

\title{
Benatti $\mathrm{MN}^{1^{*}}$
}

${ }^{1}$ Instituto de Botânica, Seção de Micologia e Liquenologia, Caixa Postal 68041, São Paulo / SP, CEP 04045-972, Brazil. michel_benatti@yahoo.com.br

Benatti MN 2012 - Three resurrected species of the genus Bulbothrix Hale (Parmeliaceae, Lichenized Fungi). Mycosphere 3(1), 46-55, Doi 10.5943/mycosphere/3/1/5

Bulbothrix laeviuscula, B. pseudocoronata and B. subscortea are proposed as new combinations in the Parmeliaceae based on type studies. Descriptions are presented and their characters discussed.

Key words - bulbate cilia - Bulbothrix fungicola - Bulbothrix goebelii - Bulbothrix isidiza Bulbothrix viridescens - Parmeliaceae

Article Information

Received 7 October 2011

Accepted 26 January 2012

Published online 19 February 2012

*Corresponding author: Michel N. Benatti - e-mail - michel_benatti@yahoo.com.br

\section{Introduction}

The genus Bulbothrix Hale (Hale 1974) is based on the Series Bicornutae (Lynge) Hale $\&$ Kurokawa of the genus Parmelia Acharius. Its species are easily identifiable by the small, deeply laciniate thalli with marginal bulbate cilia (the main characteristic), atranorin as cortical substance (what differentiates it from the genus Relicina), hyaline, unicellular, ellipsoid or bicornute ascospores, and bacilliform to bifusiform conidia. The medullary chemistry is variable, containing several substance sets and some unknown substances. Hale (1976) bundled all available taxonomic information in a monograph. Afterwards several additional taxa have been found, mainly in the Neotropics (e.g., Aptroot \& Aubel 1999, Elix 1993, 1995, Hale 1986, Jungbluth et al. 2008, Krog 1993, Marcelli 1993, Marcelli \& Ribeiro 2002, Morales-Méndez et al. 1995, Sérusiaux 1984, Sipman \& Aubel 1992, Spielmann \& Marcelli 2008) and a revision of the genus became opportune. During this (Benatti 2010) many type specimens were examined, which resulted in new interpretations of some names treated as synonyms by Hale (1976). Consequently three new combinations are presented here.

\section{Methods}

The morphological and anatomical characters of the specimens were analysed using standard stereoscopic and compound microscopes. Anatomical sections, including those of apothecia and pycnidia when present, were made with a razor blade by hand. The chemical constituents were checked by spot tests with potassium hydroxide $(\mathrm{K})$, sodium hypochlorite (C) and para-phenylenediamine $(\mathrm{P})$, and also examined under UV light (360 $\mathrm{nm})$. Chemical constituents were identified by thin-layer chromatography (TLC) using solvent C (Bungartz 2001), and compared with the data on labels left with the specimens.

The morphological terms for lobe development are in agreement with recent publications, with two exceptions. Lacinules are adventitious, ribbon-like secondary outgrowths from the primary lobe margins or sometimes from the upper surface. Lobules are similar, but 
short and rounded (Marcelli et al. 2011).

\section{Bulbothrix laeviuscula (Räsänen) Benatti \& Marcelli, comb. et stat. nov. Fig. 2 MycoBank: MB 519637}

Basionym - Parmelia marginalis var. laeviuscula Räsänen, Arch. Soc. Zool. Bot. Fenn. Vanamo 2: 45, 1947.

Holotype - Uruguay, Depto. Canelones, Carrasco National Park, arboricola, leg. I.M. Lamb 3081, 22-II-1946 (H! designated by Hale 1976, but cited as lectotype).

Thallus fragments up to $2.8 \mathrm{~cm}$ wide, subcoriaceous, corticolous, becoming dusky grey in the herbarium; upper cortex 7.5-12.5 $\mu \mathrm{m}$ thick, algal layer 37.5-50.0 $\mu \mathrm{m}$ thick, medulla 20.0-30.0 $\mu \mathrm{m}$ thick, lower cortex 10.0-17.5 $\mu \mathrm{m}$ thick. Laciniae sublinear, 0.4-1.7 $\mathrm{mm}$ wide, dichotomously, anisotomically to irregularly branched, imbricate to crowded, adnate, attached; apices plane to involute, truncate to subtruncate; margin subcrenate to crenate or irregular, flat, entire to incised, often sublacinulate, ciliate, axils oval to irregular. Upper surface continuous, smooth to subrugose with few occasional irregular cracks, laminal ciliary bulbs common, small and frequent; maculae absent. Adventitious lacinules scarce on older parts, very short, simple to furcate or irregularly branched, flat, $0.2-0.8 \times 0.1-0.4$ $\mathrm{mm}$, truncate, underside concolorous with the lower margin. Cilia black, simple or without apices, $0.05-0.10(-0.15) \times$ ca. $0.03 \mathrm{~mm}$, sometimes bent down, with semi-immersed to emersed basal bulbs ca. $0.05 \mathrm{~mm}$ wide, frequent along the margins, spaced $0.05-0.15 \mathrm{~mm}$ from each other to rarely contiguous mainly in the laciniae axils, absent or scarce at the laciniae apices. Medulla white. Soredia, pustulae and isidia absent. Lower surface black, slightly shiny to opaque, smooth to rugose, moderately rhizinate; marginal zone brown, attenuated, ca. $0.5 \mathrm{~mm}$ wide, sometimes black and indistinct from the center, slightly shiny, smooth, weakly papillate, partially rhizinate; rhizines black, occasionally dark brown when next to the margins, simple to furcate or sometimes irregularly ramified, without basal or dislocated bulbs, $0.10-0.30(-0.45) \times$ ca. $0.05 \mathrm{~mm}$, frequent, homogeneously distributed. Apothecia laminal or submarginal, common, concave, 0.2-
$1.7 \mathrm{~mm}$ diam., substipitate, margins smooth when young, then subcrenate, occasionally interrupted by ciliary bulbs, amphithecia smooth, normally with many ciliary bulbs, irregularly coronate (see comments); discs light brown, epruinose, imperforate, epithecium 7.5$10.0 \mu \mathrm{m}$, hymenium $42.5-62.5 \mu \mathrm{m}$, subhymenium 20.0-27.5 $\mu \mathrm{m}$; ascospores subspherical to ellipsoid, 5.0-8.5 × 4.0-5.5 $\mu \mathrm{m}$, epispore ca. $0.75 \mu \mathrm{m}$ thick; pycnidia laminal, common, immersed, with brown or black ostioles (hard to discern amidst the many laminal ciliary bulbs); conidia bacilliform to weakly bifusiform, 5.0 $9.0 \times$ ca. $0.75 \mu \mathrm{m}$.

Color reactions - upper cortex $\mathrm{K}+$ yellow, UV-; medulla $\mathrm{K}-$, $\mathrm{C}-$-, $\mathrm{KC}-$, $\mathrm{P}-$, UV-.

TLC - cortical atranorin; no medullary substances (see also Hale 1976).

Distribution - Uruguay (Räsänen 1947).

Additional specimens examined: Uruguay, Depto. Montevideo, planted grove of Pinus \& Eucalyptus, Charrasco National Park (Franklin D. Roosevelt National park), leg. H.A. Imshaug \& R.C. Harris 42530, 23-II-1968 (MSC). Idem., Dept. Maldonado, Sierra de las Animas, on branches of Dodonea viscosa along the road to the Mirador Nacional, $34^{\circ} 42^{\prime}$ 'S, $55^{\circ} 19^{\prime} \mathrm{W}$, ca. $200 \mathrm{~m}$, leg. H.S. Osorio 2305, 20II-1950 (US). Idem., Piriapolis, Cerro Del Toro, southern slope of the hill, on trunk of Dodonea viscosa, 50-100 m, leg. H.S. Osorio 4584, 01V-1961 (US). Brazil, Rio Grande do Sul State, Itapuã Municipality, Praia da Pedreira, leg. S.M. Martins \& A. Lemos 197, 02-VII-2003 (HAS)

Comments - Bulbothrix laeviuscula is characterized by the narrow, sublinear laciniae, the emaculate upper surface commonly with small laminal ciliary bulbs, bulbate cilia with simple or without apices, a black underside with brown margins, simple to irregularly branched rhizines without basal or dislocated bulbs, irregularly coronate apothecia with ciliary bulbs in the amphitecium, containing small, subellipsoid ascospores, and by the lack of medullary substances.

This species was treated by Hale (1976) as a synonym of $B$. viridescens (Lynge) Hale ( $S$ lectotype!), and has similar laciniae, cilia and rhizinae. However, the analyzed specimens of B. laeviuscula deviate from the lectotype, a 
duplicate $(\mathrm{W} !)$ and other specimens examined (Marcelli 8076a, SP, and Fleig \& Riquelme $125,147, \mathrm{ICN})$ of $B$. viridescens by the presence of laminal and amphitecial ciliary bulbs, irregular coronate apothecia and larger ellipsoid ascospores 5.0-9.0 × 4.0-5.5 $\mu \mathrm{m}$. In contrast, $B$. viridescens develops at no stage laminal or amphithecial ciliary bulbs, and curiously, this species can present both regular coronate and ecoronate mature apothecia on the same thallus. The confusion may have arisen from the numerous pycnidia seen in $B$. viridescens, which resemble ciliary bulbs, but differ by the typical structure containing conidiogenous hyphae and conidia, instead of the idioblast roundish cells and an oily substance (Hale 1974, Feuerer \& Marth 1997, Benatti 2011).

Similar laminal ciliary bulbs occur in $B$. bulbochaeta (Hale) Hale (LWG holotype!), which shares also the absence of propagules and the medullary chemistry. However, this species, known so far only from the palaeotropics (Hale 1976), differs by the smaller and more rounded ascospores measuring ca. $4.0-6.0 \times 4.0-5.0 \mu \mathrm{m}$, the larger laciniae (ca. 1.0-2.5 mm wide), much thicker thalli (ca. 120-200 $\mu \mathrm{m}$ thick) and the more branched cilia and rhizinae.

The material from Uruguay mentioned by Hale (1976) as B. viridescens may actually be $B$. laeviuscula. The specimens are cited as "strongly pycnidiate" and with "pycnidiate amphithecia", which might actually be laminal and amphithecial ciliary bulbs. As to reports of B. viridescens from Argentina by Adler (1988), the description fits quite well with our concept of B. laeviuscula, including the laminal ciliary bulbs that were noted by the author. However, no vouchers could be localized at IMG.

Bulbothrix semilunata (Lynge) Hale (S holotype!) differs by the narrower laciniae (ca. $0.2-0.5 \mathrm{~mm}$ wide), dichotomously ramified cilia and rhizinae, and by the more regularly coronate apothecia containing larger, bicornute, sigmoid or crescent-shaped ascospores (12.0$23.0 \mu \mathrm{m}$ long).

Bulbothrix subscortea (Asahina) Marcelli \& Benatti, comb. nov. Fig. 3
Basionym - Parmelia subscortea Asahina, Journal of Japanese Botany 32: 99, 1957.

Holotype - Taiwan, Keitau, saxicolous, leg. Y. Asahina 3324, 24-XII-1933 (TNS!, designated by Hale 1976, but cited as lectotype).

Thallus fragments up to $8.0 \mathrm{~cm}$ wide, subcoriaceous, saxicolous, becoming light dusky in the herbarium; upper cortex 10.0-15.0 $\mu \mathrm{m}$ thick, algal layer $20.0-27.0 \mu \mathrm{m}$ thick, medulla 67.5-85.0 $\mu \mathrm{m}$ thick, lower cortex $12.5-15.0 \mu \mathrm{m}$ thick. Laciniae subirregular to sublinear, (0.9-)1.6-4.5(-5.5) $\mathrm{mm}$ wide, irregularly to sometimes dichotomously anisotomically branched, slightly imbricate becoming more or less crowded in the center, adnate, loosely attached; apices plane, subrounded to sometimes subtruncate; margin smooth and sinuous or irregular, \pm flat, entire, rarely sublacinulate, ciliate, axils oval. Upper surface continuous, smooth, becoming irregularly cracked in some parts of the center, laminal ciliary bulbs absent; maculae absent (scars left by fallen isidia might resemble them). Adventitious lacinules scarce and restricted to older parts, short, simple or sometimes irregularly branched, flat, $0.2-0.9 \times 0.1-0.3$ $\mathrm{mm}$, truncate, underside concolorous with the lower margin. Cilia black, simple and long, $0.05-0.80 \times$ ca. $0.03 \mathrm{~mm}$, with semi-immersed to emerse basal bulbs $0.05-0.35 \mathrm{~mm}$ wide, frequent along the margins, spaced $0.05-0.10$ $\mathrm{mm}$ from each other to contiguous on the laciniae axils, scarce at the laciniae apices. Medulla white. Soredia and pustulae absent. Isidia abundant, laminal, granular to smoothly cylindric, straight to slightly tortuous, $0.05-0.40(-0.55) \times$ ca. $0.05 \mathrm{~mm}$, simple to sometimes slightly branched, erect, firm to caducous, concolorous or with brown apices when more developed, eciliate. Lower surface light brown except for slightly darker venations and some few scattered spots, shiny, smooth to subrugose, densely rhizinate; marginal zone light brown, usually indistinct from the center, sometimes slightly darker or rarely blackish, shiny, smooth to subrugose or venate, weakly papillate, partially rhizinate; rhizines light brown to brown, simple, with basal or displaced darkened bulbs, $0.05-0.70 \times 0.03-0.05 \mathrm{~mm}$, abundant becoming less frequent close to the 
margins, homogeneously distributed. Apothecia not found, but according to Asahina (1957) cupuliform, up to $5.0 \mathrm{~mm}$ diam., margins incurved and crenulate, amphithecia smooth, concolorous to the thallus; no mention of any kind of ornamentations; discs ferruginous brown, epruinose, hymenium ca. $50 \mu \mathrm{m}$, reaching 90 $\mu \mathrm{m}$ including epithecium and subhymenium; ascospores ellipsoid, 8 per asci, $16.0 \times 9.0 \mu \mathrm{m}$; pycnidia not found.

Color reactions - upper cortex $\mathrm{K}+$ yellow, $\mathrm{UV}-$; medulla $\mathrm{K}+$ yellow $\rightarrow$ dark red, $\mathrm{C}-, \mathrm{KC}-, \mathrm{P}+$ yellow, $\mathrm{UV}-$.

TLC - cortical atranorin; medullary salazinic acid (fide Asahina 1957, Hale 1976).

Distribution - Asia: India, Nepal, Taiwan (Asahina 1957).

Additional specimen examined: Japan, Izu, Central Japan, Simoda, Mt. Buzan, leg. S. Kurokawa 58628, 02-XII-1958 (US).

Comments - Bulbothrix subscortea is characterized by the broad, subirregular laciniae, an emaculate upper surface, simple cilia, simple to little ramified isidia, a usually light brown underside, simple brown rhizinae with basal or dislocated dark bulbs, and the presence of medullary salazinic acid. Asahina (1957) described apothecia, but there are none in the lectotype material. The author also described the laciniae width twice as large as found in the lectotype $(1 \mathrm{~cm})$.

Bulbothrix subscortea resembles $B$. isidiza closely but there are several differences which set them clearly apart: the thallus is stiff instead of membranaceous, saxicolous instead of (mostly) corticolous; the upper surface is smooth and maculate instead of rough, rugged, and emaculate; the cilia have usually longer apices, up to 0.8 instead of up to $0.3 \mathrm{~mm}$; and the rhizines have basal or displaced bulbs, instead of being without these structures.

Hale (1976) treated Parmelia subscortea as a synonym of $B$. isidiza (H-Nyl!, holotype; mentioned as lectotype by Hale 1976). Swinscow \& Krog (1988), Elix (1994), Kurokawa \& Lai (2001) and Divakar \& Upreti (2005) apparently followed his concept, because they cite saxicolous specimens of $B$. isidiza, which do probably all belong to $B$. subscortea .

There are several further Bulbothrix species with salazinic acid and isidia. These can be distinguished as follows. Bulbothrix tabacina (Montagne \& Bosch) Hale (L!, lectotype, selected by Hale 1976) is corticolous, has similar wide laciniae $1.5-4.5 \mathrm{~mm}$ but with a maculate upper surface, eciliate isidia without bulbs and a black lower side with brown margins. Bulbothrix australiensis Hale (US!, holotype) is also corticolous and has narrower, sublinear laciniae $(0.5-2.0 \mathrm{~mm}$ wide), eciliate and longer isidia without bulbs, up to $1.0 \mathrm{~mm}$ long, and a brown to light brown lower side. Bulbothrix subglandulifera (Hue) Hale (PC!, holotype, mentioned as lectotype by Hale 1976) also differs by the narrower laciniae (ca. $0.5-1.5 \mathrm{~mm}$ wide), more ramified and partially ciliate isidia with small ciliary bulbs, rhizinae with basal bulbs, and smaller ascospores usually $6.0-10.0 \times 5.0-8.0 \mu \mathrm{m}$.

The morphologically similar and equally saxicolous Bulbothrix cinerea Marcelli \& Kalb (herb. Kalb!, holotype) has thallus with a deeper grey tonality, eciliate isidia always with blackish apices, coronate apothecia, and medullary norstictic acid. The equally similar and norstictic acid-containing $B$. ventricosa (Hale \& Kurokawa) Hale (TUR-V!, lectotype) is corticolous, and differs by the variable coloration of the lower cortex, the coronate apothecia and also by the laminal ciliary bulbs.

Bulbothrix pseudocoronata (Gyelnik) Benatti \& Marcelli, comb. nov. MycoBank: MB 561687

Fig. 4

Basionym - Parmelia pseudocoronata Gyelnik, Fedde's Repertorium Specierum Novarum 29: 289, 1931.

Synonyms - Parmelia coronata f. isidiosa Müller Argoviensis, Revue Mycologique 10: 56, 1888.

Lectotype - Paraguay, Cerro Yaguarón, sur l'écorce des arbres, leg. Balansa 4176, $17-$ VI-1879 (G! selected by Hale 1976; duplicates at $\mathrm{M}$ ! and $\mathrm{W}$ !).

Bulbothrix lacinulata Marcelli, Jungbluth \& Elix, Mycotaxon 104: 54, 2008. (Brazil, São Paulo State, Itirapina Municipality, Estação Ecológica do Instituto Florestal, $22^{\circ} 15^{\prime} \mathrm{S} 47^{\circ} 49^{\prime} \mathrm{W}, 770 \mathrm{~m}$ alt., woodland, on a tree trunk, L.S. Canêz, P. Jungbluth \& A.A. Spielmann 1083A, 27-III-2004, SP!, holotype). Thallus fragments up to $4.5 \mathrm{~cm}$ wide [entire 
thalli up to $5.4 \mathrm{~cm}$ wide], submembranaceous, corticolous, becoming light dusky grey in the herbarium; upper cortex 7.5-15.0 $\mu \mathrm{m}$ thick, algal layer $10.0-25.0 \mu \mathrm{m}$ thick, medulla 20.0-40.0 $\mu \mathrm{m}$ thick, lower cortex 12.5-22.5 $\mu \mathrm{m}$ thick. Laciniae sublinear, 0.1-0.6(-1.0) $\mathrm{mm}$ wide, dichotomously anisotomic to irregularly branched, contiguous becoming little imbricate or crowded at the center, tightly adnate, strongly attached; apices plane, truncate to subtruncate; margin smooth and sinuous to subcrenate or irregular, flat, entire to slightly incised, commonly sublacinulate, ciliate, axils oval or subirregular. Upper surface continuous, smooth, frequently hidden by lacinulae except at distal parts [with occasional transversal cracks], laminal ciliary bulbs absent; maculae absent (see comments). Lacinules frequent to abundant, marginal to laminal, short, subcanaliculate or semi-cylindrical like cleaved isidia to flat and lingulate, those laminal ascending and procumbent, simple or irregularly branched, $0.10-0.80 \times 0.05-0.20 \mathrm{~mm}$, truncate or acute, ciliate, underside concolorous with the lower margin light brown. Cilia black, apices absent or simple to partially furcate, $0.05-0.10(-0.15)$ $\times$ ca. $0.03 \mathrm{~mm}$, with semi-immersed basal bulbs ca. $0.05(-0.10) \mathrm{mm}$ wide, abundant along the margins, spaced ca. $0.05 \mathrm{~mm}$ from each other to occasionally contiguous, scarce or absent at the laciniae apices or on the most densely lacinulate margins. Medulla white. Soredia and pustulae absent. Isidia absent (but see lacinulae). Lower surface black to dark brown, shiny, smooth to subrugose, weakly papillate, slightly to moderate to densely rhizinate; marginal zone light brown, attenuate, ca. $0.5 \mathrm{~mm}$ wide, shiny, smooth to weakly papillate, partially rhizinate; rhizines black to dark brown or rarely light brown, simple to partially furcate, frequently with basal bulbs, $0.05-0.30 \times$ ca. $0.03 \mathrm{~mm}$, frequent to abundant, homogeneously distributed. Apothecia laminal, absent to common, plane to convex, coronate with small bulbs, 0.2-2.3 $\mathrm{mm}$ diam., adnate, margins smooth to subcrenate, amphithecia smooth, sometimes with few lacinulae or scarce ciliary bulbs; discs light brown, epruinose, imperforate, epithecium 10.0-12.5 $\mu \mathrm{m}$, hymenium 20.0-32.5 $\mu \mathrm{m}$, subhymenium 17.5-25.0 $\mu \mathrm{m}$; ascospores (not found on type, hymenium without asci) subrounded to ellipsoid, (5.0-)7.0-9.5 × 4.5-5.5 $\mu \mathrm{m}$, epispore ca. 1.0 $\mu \mathrm{m}$; pycnidia scarce to abundant, laminal to submarginal or on the lacinulae, immersed, with black ostioles; Conidia (not found on type) bacilliform to weakly bifusiform, 5.0-8.0 $\times 1.0$ $\mu \mathrm{m}$.

Color reactions - upper cortex $\mathrm{K}+$ yellow, UV-; medulla $\mathrm{K}-$ or + weak yellowish, $\mathrm{C}+$ rose to reddish rose, $\mathrm{KC}+$ rose to reddish rose, $\mathrm{P}-$ or + weak yellowish, UV-. (Occasional yellowish $\mathrm{K}$ and $\mathrm{P}$ medullary reactions are probably due to small amounts of atranorin).

TLC/HPLC - cortical atranorin and chloroatranorin; medullary gyrophoric (major) and lecanoric (minor/traces/absent) acids (see also Hale 1976, Jungbluth et al. 2008).

Distribution - South America: Paraguay (Müller Argoviensis 1888, sub Parmelia coronata f. isidiosa), Brazil: SP (Jungbluth 2006, Jungbluth et al. 2008, sub Bulbothrix lacinulata). This species was treated by Hale (1971 1976) as a synonym of B. fungicola, and due to a confusion involving these species and also $B$. suffixa and $B$. lacinulata; the distributions of $B$. fungicola and $B$. pseudocoronata are possibly mixed. Additional

Specimen examined - Dominican Republic, Prov. Santiago, pine forest on ridge around hospital north of San Jose de las Matas, leg. H.A. Imshaug \& C.M. Wetmore 3881, 17VIII-1958 (US). Dominica, Bois Serpé (trail from South Chiltern to Soulfrière Bay), ca. $1000 \mathrm{ft}$., Parishes of St. Luke and St. Marks, H.A. Imshaug \& F.H. Imshaug 32758, 6-XI1963 (MSC). Trinidad, South slope of El Tucuche (above gap between El Tucuche and Naranja), north of St. Joseph, Northern Range, leg. H.A. \& F.H. Imshaug 32971, 13-X-1963 (MSC). Honduras, Distrito Central, above San Juancito, along a trail in the cloud forest, on a freshly felled Liquidambar, elev. above 6410 ft., leg. W.L. \& C.F. Culberson 18423, 29-XII1979 (DUKE). Paraguay, Depto. Paraguarí, Parque Nacional Ybycuí, along road/trail to Salto Mbocaruzú on Rio Corrientes, ca. $200 \mathrm{~m}$, ca. $26^{\circ} 05^{\prime} \mathrm{S}, 56^{\circ} 53^{\prime} \mathrm{W}$, dry forest and extensive sandstone outcrops in cerrado, on palm trunk, leg. W.R. Buck 12082, 6-X-1984 (NY). Brazil, Pará, Serra do Cachimbo, aprox. $10 \mathrm{~km} \mathrm{~N}$ of Base Aérea do Cachimbo, along the 

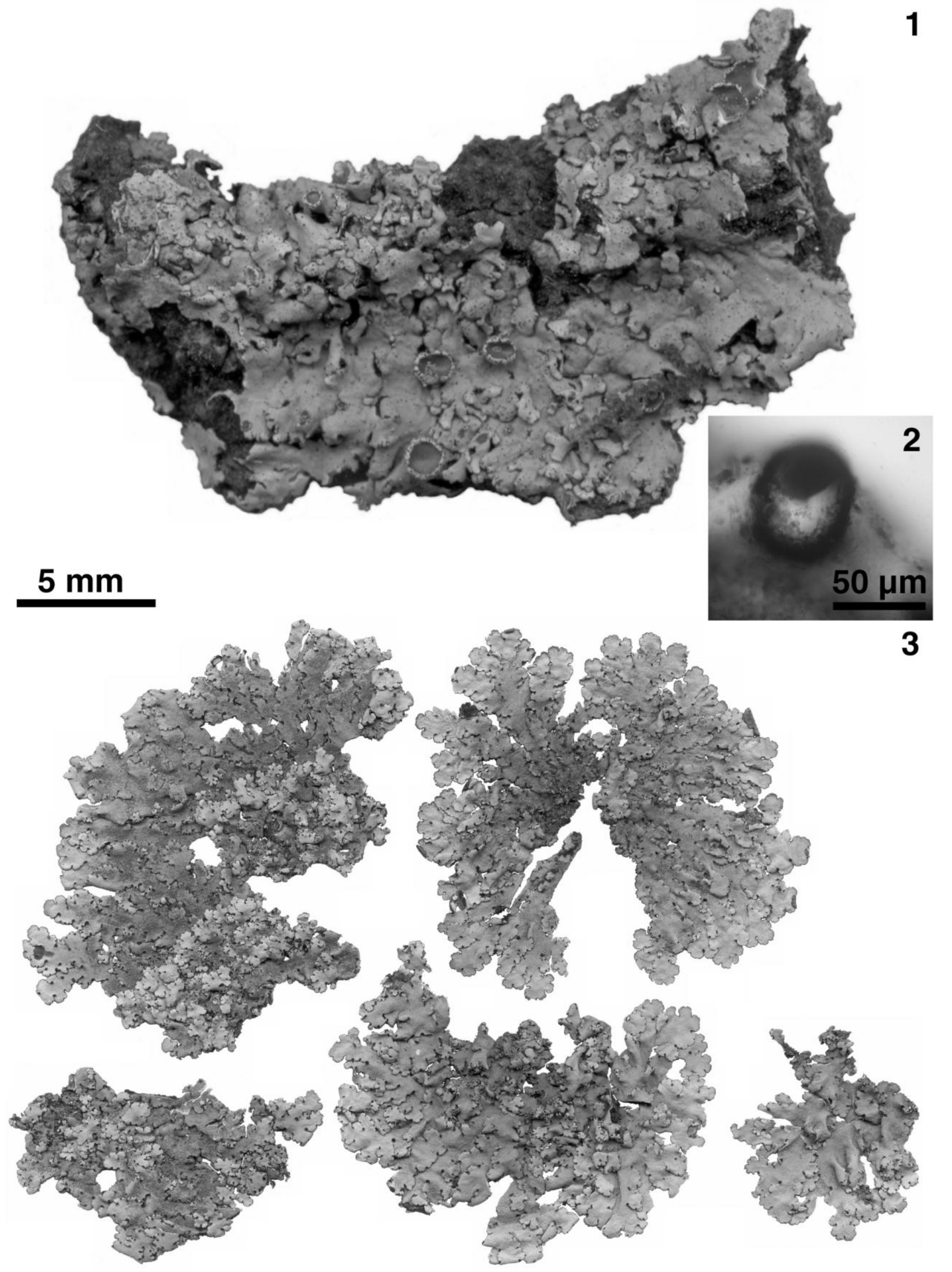

Figs 1-3 The type specimens of B. laeviuscula and B. subscortea. 1 Holotype of B. laeviuscula. 2 Detail of a tiny laminal ciliar bulb cut showing the internal cells and escaping oily substance. $\mathbf{3}$ Holotype of $B$. subscortea. Bars $=1 \mathrm{~cm}$, except when indicated. 
Cuiaba-Santarém highway (BR-163), ca. $9^{\circ} 22^{\prime} \mathrm{S}, 54^{\circ} 54^{\prime} \mathrm{W}$, ca. 430-480 m, leg. L. Brako \& M.J. Dibben 6280, 28-IV-1983 (NY). Idem., Mato Grosso, BR-163 highway, km 37 of the Coxim-Rondonópolis stretch, near Itiquira River, $500 \mathrm{~m}$ alt., cerrado, on tree trunk, leg. M.P. Marcelli 8448, 8450, 30-VI-1980 (SP). Idem., São Paulo, Cachoeira das Emas Municipality, $530 \mathrm{~m}$ alt., annually burnt cerrado field, over mangabeira trunk (Hanchornia speciosa Gomes), leg. M.P. Marcelli 16351, 16353, 23-IX-1978 (SP). Idem., Santa Rita do Passa Quatro Municipality, Vassununga farm, km 259 of the Anhanguera Highway, $760 \mathrm{~m}$ alt., transition from cerrado to cerradão, on twig, leg. M.P. Marcelli \& B.L. Morretes 16056, 27-IX-1978 (SP). Idem., Itirapina Municipality, Estação Ecológica do Instituto Florestal, dense cerrado, on tree trunk, leg. L.S. Canêz, P. Jungbluth \& A.A. Spielmann 1083, 27-III-2004 (SP). Idem., Mogi-Guaçu Municipality, Reserva Biológica de MogiGuaçu, Campininha farm, on tree trunk at cerradão border, M.P. Marcelli \& A.E. Luchi 34658, 19-IX-2000 (SP).

Comments - Bulbothrix pseudocoronata is characterized by the sublinear, narrow laciniae, an emaculate upper surface densely covered by semi-cylindrical to subcanaliculate or flat lacinulae, simple or furcate cilia, a black lower cortex with brown margins, simple to furcate rhizinae with basal bulbs, coronate apothecia containing rounded to ellipsoid small ascospores, and by the presence of gyrophoric acid as main medullary substance.

In the protologue of Parmelia coronata f. isidiosa Müller Argoviensis (1888) mentions very ramified and abundant isidia, leaving free only the apical parts of the laciniae. Despite the several apothecia in the duplicates, the author mentioned that ascospores were not found. Vainio (1890) separated $P$. coronata f. isidiosa from $P$. coronata Fée by the "infrequently" isidiate thallus. As further details he mentions light colored, not cracked and emaculate thalli, with much larger laciniae $(0.5-2.5 \mathrm{~mm}$ wide), with whitish isidia(?), a densely rhizinate black lower cortex, and negative K- and C-reactions. $\mathrm{He}$ also mentions imperforate apothecia ornamented with isidia and black spots (corona?), with a brown epithecium, hymenia ca. $70 \mu \mathrm{m}$ high, ellipsoid ascospores 14.0-18.0 $\times 9.0-12.0 \mu \mathrm{m}$. The spores are much larger than we observed in our material, therefore it is possible that Vainio had a different species at hand. Gyelnik (1931) raised $P$. coronata f. isidiosa to species level using a new epithet, $P$. pseudocoronata, but without adding any description or comment.

The lectotype of Parmelia coronata f. isidiosa and B. pseudocoronata, selected by Hale (1976), consists of two fragments in good condition, only slightly damaged at some parts, on tree bark. There are few pycnidia (conidia were not found), and only one underdeveloped apothecium without asci in the hymenium. The duplicate from $\mathrm{W}$ consists of two smaller fragments, which are in even better condition, with more flat lacinulae, pycnidia and apothecia. The duplicate from $\mathrm{M}$ is also in good condition, consisting of two small fragments 2 $\mathrm{cm}$ diam. and one ca. $5 \mathrm{~cm}$ diam., has virtually the same proportion of semi-cylindrical and flat lacinulae, and several full-grown apothecia without asci.

The material fits well the description of B. lacinulata (Jungbluth \& Marcelli 2008), and since Parmelia pseudocoronata antedates $B$. lacinulata, the latter becomes a synonym of $B$. pseudocoronata. It deviates cleary from $B$. fungicola (Lynge) Hale, where the species had been included before as synonym (e.g., Hale 1976), by the presence of abundant lacinules rather than rather scattered, cylindrical isidia. While $B$. fungicola produces only short, cylindrical isidia, $B$. pseudocoronata has longer lacinulae, which may look like isidia at very early stages, but become flattened soon. Also the first has more abundant rhizinae without basal bulbs, while in $B$. pseudocoronata the rhizinae are less frequent and commonly with basal bulbs. One of the fragments that compose the type collection of B. fungicola (S!) is in fact of $B$. pseudocoronata, and the probable reason why Lynge (1914) and Hale (1976) believed that $B$. fungicola formed isidia as well as laminal lacinulae and were inclined to accept $B$. pseudocoronata as a synonym of $B$. fungicola.

For differentiation from this and other similar species, see also Jungbluth \& Marcelli 2008, Table 1. To this can be added, that the spores of $B$. pseudocoronata (B. lacinulata) 


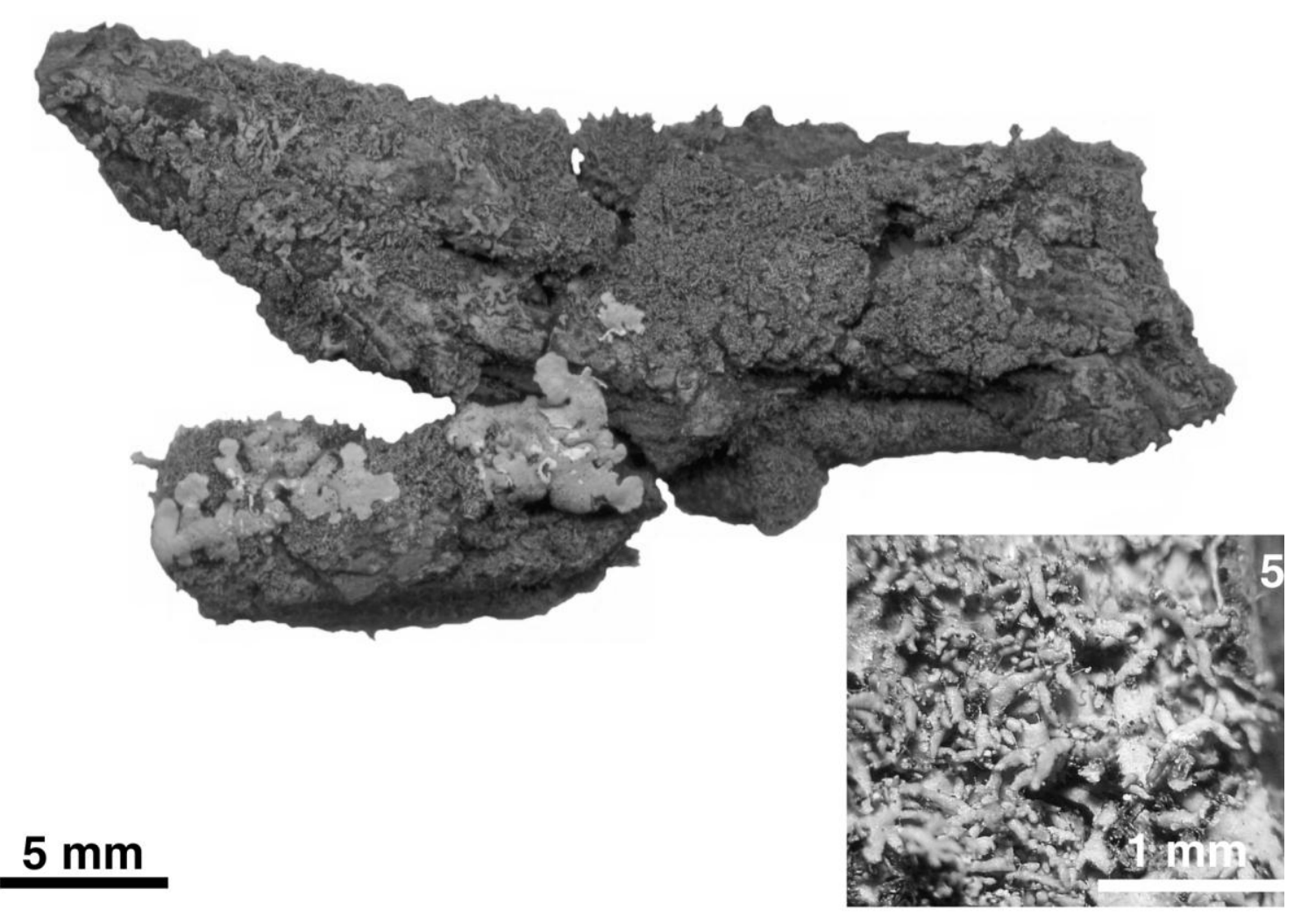

Figs 4-5 The type specimen of B. pseudocoronata. 4 Lectotype of B. pseudocoronata. 5 Detail of the lacinulae of $B$. pseudocoronata. Bars $=1 \mathrm{~cm}$, except when indicated.

measure $(5.0-) 7.0-9.5 \times 4.5-5.5 \mu \mathrm{m}$, which is slightly smaller than in $B$. suffixa.

The species is perhaps most easily confusable with $B$. suffixa (Stirton) Hale, because of the presence of lacinules, used as a key character for $B$. suffixa by, e.g., Hale (1976). The type material of B. suffixa (Stirton) Hale (BM!, duplicate at GLAM!) is the probable cause of the confusion between these species. It is very immature and it is not possible to be sure if it develops laminal lacinulae, isidia, or both. Jungbluth et al. (2008) suggest that the lacinules are scarce and merely adventitious, 0.1-0.6 mm long. A difference may be in the wider laciniae, $0.5-1.5 \mathrm{~mm}$ wide.

\section{Acknowledgements}

The author wishes to thank the curators of BM (Scott LaGrecca), DUKE (Kathleen Pryer), G (Philippe Clerc), H (Leena Myllys), HAS ( Suzana M. A. Martins), ICN (Mara R.
Ritter), LWG (Tariq Husain), M (Andreas Beck), MSC (L. Alan Prather), GLAM (Keith Watson), NY(Barbara Thiers), PC (Bruno Dennètiere), S (Anders Tehler) TNS (Yoshihito Ohmura), TUR (Seppo Huhtinen), U (Erik Smets),US (Rusty Russell) and W (Uwe Passauer) for the loans of the type specimens and additional materials, Dr. Harrie Sipman for the linguistic review, comments, and suggestions, and the reviewers for critical revision of the manuscript.

\section{References}

Adler M. 1988 - La família Parmeliaceae (Liquenes Ascomycotina) en la província de Buenos Aires: estúdio taxonomicofloristico. Thesis, Universidad de Buenos Aires.

Aptroot A, Aubel RJMT. 1999 - Bulbothrix sipmanii, a new lichen species from 
Guyana. Mycotaxon 71, 139-140.

Asahina Y. 1957 - Lichenologische Notizen (124-125). The Journal of Japanese Botany 32, 97-100.

Benatti MN. 2010 - Revisão taxonômica do gênero Bulbothrix Hale (Parmeliaceae, Ascomycota liquenizados). Thesis, Instituto de Botânica.

Benatti MN. 2011 - Two new species of Bulbothrix Hale. Mycology (in press).

Bungartz F. 2001 - Analysis of lichen substances. ASU lichen herbarium. http://nhc.asu.edu/ lichens/lichen_info/ tlc.jsp\#TLC2. Accessed 20 July 2008.

Divakar PK, Upreti DK. 2005 - Parmelioid Lichens in India - a Revisionary Study. Bishen Singh Mahendra Pal Singh, Dehra Dun-248 001.

Elix JA. 1993 - New species in the lichen family Parmeliaceae (Ascomycotina) from Australia. Mycotaxon 47, 101-129.

Elix JA. 1994 - Bulbothrix. In: Flora of Australia, Lichens. Introduction, Lecanorales 2, vol. 55. (eds AE Orchard, C Grgurinovic). Australia Government Publishing Service, Canberra 13-19.

Elix JA. 1995 - New species in the lichen family Parmeliaceae (Ascomycotina) from Australasia and Malaysia. Mycotaxon 56, 231-241.

Gyelnik V. 1931 - Additamenta ad cognitionem Parmeliarum. II. Feddes repertorium specierum novarum regni vegetabilis 29 , 273-291.

Hale ME. 1971 - Morden-Smithsonian Expedition to Dominica: the lichens (Parmeliaceae). Smithsonian Contributions to Botany 4, 1-25.

Hale ME. 1974 - Bulbothrix, Parmelina, Relicina, and Xanthoparmelia, four new genera in the Parmeliaceae. Phytologia 28, 479-490.

Hale ME. 1976 - A monograph of the lichen genus Bulbothrix Hale (Parmeliaceae). Smithsonian Contributions to Botany 32, $1-29$.

Hale ME. 1986 - New species in the lichen Family Parmeliaceae (Ascomycotina). Mycotaxon 25, 85-93.

Jungbluth P. 2006 - A família Parmeliaceae (fungos liquenizados) em fragmentos de cerrados do Estado de São Paulo. Dissertation, Instituto de Botânica, São Paulo.

Jungbluth P, Marcelli MP, Elix JA. 2008 - Five new species of Bulbothrix (Parmeliaceae) from cerrado vegetation in São Paulo State, Brazil. Mycotaxon 104, 51-63.

Krog H. 1993 - Parmelina enormis (Hale) Hale is Bulbothrix enormis (Hale) Krog comb. nov. Lichenologist 25, 299-300.

Kurokawa S, Lai MJ. 2001 - Parmelioid lichen genera and species in Taiwan. Mycotaxon 77, 225-284.

Lynge B. 1914 - Die Flechten der ersten Regnellschen Expedition. Die Gattungen Pseudoparmelia gen. nov. und Parmelia Ach. Arkiv för Botanik 13, 1-172.

Marcelli MP. 1993 - Pequenas Parmelia s.l. ciliadas dos cerrados brasileiros. Acta Botanica Brasilica 7, 25-70.

Marcelli MP, Ribeiro, CH. 2002 - Twenty-one new species of Parmeliaceae (lichenized fungi) from southeastern Brazil. Mitteilungen aus dem Institut für Allgemeine Botanik Hamburg 30-32, 125-155.

Marcelli MP, Canêz LS, Benatti MN, Spielmann AA, Jungbluth P, Elix JA. 2011 - Taxonomic novelties in Parmeliaceae. Bibliotheca Lichenologica 106, 211-224.

Morales-Méndez A, Marcano V, Galiz, L, Mohali S, Palacios-Prü E. 1995 Bulbothrix amazonensis sp. nov., a new species of Parmeliaceae (Lecanorales) from Venezuelan Amazonia. (eds FJA Daniëls, M Schulz, J Peine). In: Flechten Follmann. Contributions to lichenology in Honour of Gerhard Follmann. Geobotanical and Phytotaxonomical Study Group, Botanical Institute, University of Cologne, Cologne, 281-286.

Müller Argoviensis J. 1888 - Lichenes Paraguayenses a cl. Balansa lecti. Revue Mycologique 10, 53-68, 113-120, 178184.

Räsänen V. 1947 - Lichenes Novi III. Archivum Societatis Zoologicae Botanicae Fennicae Vanamo 2, 45-51.

Sérusiaux E. 1984 - Contribution to the study of lichens from Kivu (Zaire), Rwanda and 
Burundi. VIII. New and interesting species of parmeliaceous lichens. The Bryologist 87, 1-11.

Sipman HJM, Aubel RJMT. 1992 - New Parmeliaceae (Lichenes) from the Guianas and surroundings. Mycotaxon 44, 1-12.

Spielmann AA, Marcelli MP. 2008 - Bulbothrix viatica Spielmann \& Marcelli, a new species of Parmeliaceae from Brazil.
Mycotaxon 103, 201-205.

Swinscow TDV, Krog H. 1988 - Macrolichens of East Africa. British Museum of Natural History, London.

Vainio (Wainio) EA. 1890 - Étude sur la classification naturelle et la morphologie des Lichens du Brésil, pars prima. Acta Societatis pro Fauna et Flora Fennica 7, ixxix, 1-247. 